\title{
Dynamic Effects of Foreign Portfolio Investment on Economic Growth in Nigeria
}

http://doi.org/10.21272/fmir.4(3).5-12.2020

\section{Otapo Toyin Waliu}

Department of Banking and Finance, Adekunle Ajasin University, Akungba Akoko, Ondo State, Nigeria Adekunle Oludayo Elijah, ORCID: https://orcid.org/0000-0002-5870-9384

Department of Banking and Finance, Adekunle Ajasin University, Akungba Akoko, Ondo State, Nigeria

\begin{abstract}
The slow growth rate and the deficit of full-fledged financial security have created the preconditions for studying the relationship between foreign investment and economic growth. In previous literature, key emphases on this issue were studied in the short term and in terms of static functioning of the economy. Thus, this article purposely studied the dynamic nature of the development of the relationship between foreign investment and economic growth in Nigeria from 1980 to 2018. The use of the Augmented-Dickey Fuller test confirmed the precondition for adopting dynamic techniques to test the significant role of foreign portfolio investment (among other analyzed factors - domestic savings, government capital expenditures, market capitalization) in the formation of gross domestic product. The use of the lag selection method allowed to determine the optimal lag for estimating the autoregressive distributed model, which substantiates the effectiveness and reliability of the autoregressive distributed lag model. The information base of the study was the statistical bulletin of the Central Bank of Nigeria. The results of empirical estimations in the short term showed that domestic savings had significant and negative impact on gross domestic product. The study empirically confirms and theoretically proves that foreign investment, domestic savings, government spending and market capitalization determine long-term trends in gross domestic product formation in Nigeria. Practically, the empirical result revealed that the presence of a significant deficit of domestic savings in Nigeria creates obstacles to successful economic growth in the country both in the short and long term; portfolio foreign investment accelerates economic growth in the long run to a greater extent than in the short run.
\end{abstract}

Keywords: autoregressive distributed model, Dickie-Fuller test, economic growth, foreign investment, double gap theory.

JEL Classification: C12, O47, F21.

This work is licensed under a Creative Commons Attribution 4.0 International License

Cite as: Toyin, O.W., Oludayol Ad., E. (2020). Dynamic Effects of Foreign Portfolio Investment on Economic Growth in Nigeria. Financial Markets, Institutions and Risks, 4(3), 5-12. http://doi.org/10.21272/fmir.4(3).512.2020.

(C) The Authors, 2020. This article is published with open access at Sumy State University.

\section{Introduction}

Both underdeveloped and developing countries need adequate financial resources to stimulate economic activities and growth in the short and long run. These resources are required to promote investment, business and government activities which are germane for enhancing economic growth. However, the wave of globalization led many countries to open their economy to inflow of foreign capital to complement insufficient domestic financial resources (Akinwale \& Adekunle, 2019). Foreign portfolio investment (FPI) which is an important aspect of foreign capital involves investment in the financial instruments of a domestic country by foreign investors. These investments are cross border investment involving the purchase of securities such as cash, stock or bonds by international investors in order to make profit (Baghebo \& Apere, 2014).

Foreign portfolio investment plays significant role to developing economies. It contributes to the recipient economy through increase capital accumulation for production activities, support of new technology, improvement of balance of payments, creation of business opportunities and high tax revenue (Ngowi, 2001; Okonkwo, 2016; Mugableh \& Oudat, 2018). Furthermore, foreign portfolio investment influences economic performance of recipient nation in terms of productivities, employment generation, income distribution, 
poverty reduction and domestic investment enhancement (Gumus, Duru \& Gungor, 2013). The importance of foreign portfolio investment in developing countries was justified by the dual gap analysis theory. This theory opined that most developing countries are mainly poor nation with low savings and capital formation through which investment would be enhanced (Chenery \& Bruno, 1962; Chenery \& Strout, 1966; Adelman \& Chenery, 1966).

Most developing countries like Nigeria have the objective of promoting economic growth through the stimulation of domestic production activities. These countries need capital from developed countries where investment opportunities are lacking. Thus, the effect of foreign portfolio investment on economic growth of developing countries cannot be underestimated. Theoretically, the neoclassical growth model opined that foreign portfolio investment engender economic growth through the increase in the volume and efficiency of domestic investment (Okonkwo, 2016). This assertion is supported by endogenous growth model which stated that foreign portfolio investment propel economic growth via diffusion of technologies and other important resources from more developed economies to developing countries. Fosu and Magnus (2006) stated that foreign portfolio investment augments domestic capital which serves as a vigor to domestic investment and growth.

The attraction of foreign portfolio investment has been one of the major focuses of African nations in the recent years. According to Ngowi (2001), foreign portfolio investment is needed by African countries and other developing countries to fill the saving-investment gaps due to low rate of capital accumulation and poverty in order to promote growth. This resulted in the adoption of Structural Adjustment Programme (SAP) by most African countries in the 80s'. In Nigeria, the need to attract the inflow of foreign portfolio investment led to the implementation of SAP in 1986 which resulted in the inflow of foreign portfolio investment in the tune of \#151.6 billion (Central Bank of Nigeria Statistical Bulletin, 2018). Nigeria has continued to experience fluctuation in the inflow of foreign portfolio investment following the transition to democratic era and the formulation of diverse policies. Baghebo and Baghebo (2014) opined that Nigeria business environment has been weak especially since the return to democracy with the progress of the economy negatively affected by epileptic power supply and other important infrastructural facilities among others. Nigeria faces with high insecurity, rising social vices, inconsistencies in government policies and volatile macroeconomic variables like exchange rate and inflation rate which may have discouraging effect on foreign investors.

The weakness of Nigerian business environment has major implication in attracting foreign portfolio investment. Foreign portfolio investment has been fluctuating over time with FPI rising from $\$ 792.3$ billion in 2011 to $\$ 2687.2$ billion in 2012 and later fell to $\$ 2130.1$ billion in 2013 , $\$ 832.3$ billion in 2014, $\$ 498.1$ billion in 2015 and $\$ 476.9$ billion in 2016 before rising to $\$ 2604.3$ billion in 2017 and $\$ 3834.5$ billion in 2018 (CBN, 2018). This fluctuation according to Baghebo and Apere (2014); Okonkwo (2016); Akinmulegun (2018) resulted from inability of the domestic capital market to attract the inflow of foreign portfolio investment due to underdevelopment and inconsistency in the presentation of foreign investment profiles in the market which has implication on the ability of the economy to achieve its macroeconomic objectives of employment generation, domestic investment enhancement and economic growth stimulation. However, following the review of literature in the subject area, very few studies were conducted on flow of foreign portfolio investment in developing countries like in Nigeria. Quite a number of the reviewed studies focus on the determinants of foreign portfolio investment in the economy (Idowu 2015; Mugableh \& Oudat, 2018; Haider, Khan \& Abdulahi, 2016). Also, studies like Gumus, Duru and Gungor (2013); Okonkwo (2016); Akinmulegun (2018); Makoni and Marozva (2018); Onuoha, Okoro and Kinsley (2018); Aisien (2018) examined the relationship between foreign portfolio investment and some varaibles like capital market, industrial sector, exchange rate and macroeconomic variables.

Few works that were done on the effect of foreign portfolio investment on economic growth include the studies of Baghebo and Apere (2014); Bada (2016); Tsaurai (2017); Akinbobola, Ibrahim and Ibrahim (2017); Ibrahim and Akinbobola (2017); Ezeanyej and Maureen (2019). However, these studies mainly focus on the short run effect of foreign portfolio investment on economic growth. This study examined the short run and long run effects of foreign portfolio investment on economic growth using advanced technique of Autoregressive Distributed Lag. This technique is suitable for small sample size and correction of endogeneity in macroeconomic data. Thus, this study investigated the effect of foreign portfolio investment on economic growth by capturing important variables like domestic savings, market capitalization and government expenditure which are important determinants of economic growth and foreign Portfolio investment inflow. 
Financial Markets, Institutions and Risks, Volume 4, Issue 3, 2020 ISSN (online) - 2521-1242 ISSN (print) - 2521-1250

Following the introductory section, other parts of the paper were divided into literature review, methodology, results and discussions and finally, conclusion and recommendations.

\section{Literature Review}

Foreign portfolio investment plays significant role to developing economies. Due to insufficiency of domestic savings to stimulate investment and support the growth aspiration of an economy, the need for inflow of foreign capital to achieve higher economic growth becomes necessary in developing countries like Nigeria (Chenery \& Bruno, 1962; Chenery \& Strout, 1966)). The need for foreign portfolio investment in developing countries resulted from insufficient domestic financial resources to stimulate investment and economic activities. Akinmulegun (2018) asserted that most developing countries lack enough financial resources resulting from gap between capital and investment opportunities leading to the necessity of foreign capital inflow.

The implications of foreign portfolio investment on economic growth have been highly discussed in literature both locally and internationally. Gumus, et al., (2013) examined the relationship between foreign portfolio investments and macroeconomic factors in Turkey from 2006 to 2012 using secondary data which were analyzed with vector aggressive granger causality tests, impulse responses and variance decomposition. The study concluded that macroeconomic varaibles significantly influenced foreign portfolio investment in Turkey. Also, Haider, et al., (2016) investigated the determinants of foreign portfolio investment in China economy over the period of 1997 to 2014. The study employed OLS for analysis and established that GDP, population growth, exchange rate, and external debt had significant effect on foreign portfolio investment of China.

In a similar study, the impact of foreign portfolio equity investments on economic growth was carried out by Tsaurai (2017) in Asian and European by employing panel data from 2001 to 2014. The study employed Panel unit root and Generalised Methods of Moments Estimation techniques to examine the effect of the independent variables on the dependent variables. It was found that foreign portfolio equity investments positively influenced economic growth. However, mixed result was found between macroeconomic variables and foreign portfolio investment in West Africa by Onuoha, Okoro and Kingsley (2018) who estimated the causal and dynamic relationship between macroeconomic variables and FPI in West Africa using System GMM techniques over the period of 1990 and 2016.

Through the employment of Autoregressive Distributed Lag, Vector Error Correction Model and granger causality techniques, Makoni and Marozva (2018) investigated the direction of relationship between foreign portfolio investment and financial market development in Mauritius using secondary data from 1989 to 2016. The study showed that long run and positive relationship exit between foreign portfolio and real economic growth. Mugableh and Oudat (2018) employed Autoregressive Distributed Lag technique to investigate variables that effect foreign portfolio investments in Jordan and it was found that domestic market capitalization, foreign direct investment, money supply, and government expenditures were supportive to foreign portfolio investments in Jordan.

Baghebo and Apere (2014) investigated the impact of foreign portfolio investment on economic growth based on secondary data from 1986 to 2011 and analyzed with Augmented Dickey-Fuller (ADF) test, Johansen cointegration technique and error correction mechanism techniques. The study revealed that foreign portfolio investment, market capitalization and trade openness had positive long-run relationship with real gross domestic product in Nigeria. Augmented Dickey-Fuller, Philips-Perron, Johansen co-integration, error correction mechanism estimation and granger causality test techniques were used by Idowu (2015) to analyze the major determinants of foreign portfolio investment inflows in Nigeria using data from CBN Statistical Bulletin and the World Bank Development Index covering the period of 1970 and 2010. It was indicated that foreign portfolio investment in Nigeria have not been encouraging, as a result of major domestic flaws in the country such as high inflation, poor infrastructure, corruption and insecurity that reflect on the nominal growth of the country, low interest rate, unfavorable exchange rate and unnecessary barrier to trade and inflows of capital.

Bada (2016) focused on the impact of foreign portfolio investment on Nigerian economic growth from 1991 to 2014 analyzed with the aid of ordinary least square and it was indicated that foreign portfolio investment and other varaibles employed in the study had positive effect on economic growth in Nigeria. By focusing on industrial sector, Okonkwo (2016) found that from error correction model result that there is significant and positive relationship among foreign portfolio investment, gross fixed capital formation, market capitalization and industrial growth proxied by industrial production index (IPI) in Nigeria. Ibrahim and Akinbobola (2017) examined the relationship between foreign portfolio investment and economic growth during democracy era analyze with the aid of Augmented Dickey Fuller, Phillip Peron tests and Vector Auto-Regressive technique. 
The study concluded that foreign portfolio investment had positive effect on economic growth during democracy that military regime. Akinbobola, et al., (2017) investigated the effect of foreign direct investment on economic growth from 1986 to 2013. The techniques employed include, Augmented Dickey Fuller Test, Phillip Perron Test, Johansen Co-integration and Toda and Yamamoto Causality Technique. The study mainly found that there is bidirectional causality between foreign portfolio investment and economic growth. Aisien (2018) assessed the impact of exchange rate on foreign private investment using quarterly time series data from 2007 to 2017 analyzed with Vector Autoregressive Technique for analysis purpose. It was concluded that that devaluation/depreciation of the naira adversely affects foreign direct investment and foreign portfolio investment in Nigeria.

With the aid of Augmented Dickey Fuller Test, Granger Causality Test and Vector Error Correction Model, Akinmulegun (2018) studied the relationship between capital market development and foreign portfolio investment in Nigeria from 1985 to 2016 and it was found that capital market development had significant effect on foreign portfolio investment in Nigeria. Ezeanyej and Maureen (2019) examined the impact of foreign direct investment on economic growth in Nigeria from 1986 to 2017 using secondary data. Augmented DickeyFuller (ADF) test, The Johansen co-integration technique and the Error Correction Mechanism (ECM) were used for analyzing the data. The study concluded that foreign portfolio investments had positive significant impact on economic growth in Nigeria.

\section{Methodology}

This study is quantitative in nature and employed non- experimental research design to examine the effect of foreign portfolio investment, domestic savings, market capitalization and government capital expenditure on gross domestic product in Nigeria. Time series data were sourced from Central Bank of Nigeria Statistical (2018) from 1986 to 2018. The model for the study was anchored on Dual gap and neoclassical growth theory. The Dual Gap Theory opined that most developing countries are mainly poor nation with low savings and capital formation through which investment would be enhanced and thus need foreign capital (Chenery \& Bruno, 1962; Chenery \& Strout, 1966). The neoclassical growth theory of Solow (1956) argued that "higher portion of investment as a share of gross domestic product has the capacity to stimulate the rate of economic growth in developing countries that are capital stricken". The empirical models of Baghebo and Apere (2014); Akinbobola, et al., (2017); Ezeanyej and Maureen (2019) were adapted with a little modification thus:

$\mathrm{GPD}=f(\mathrm{FPI}, \mathrm{DS}, \mathrm{MCAP}, \mathrm{GCE})$

This is given econometrically with its logarithm form as:

$$
\text { LGDP }=\beta_{0}+\beta_{1} \text { FPIGDP }+\beta_{2} \text { LDS }+\beta_{3} \text { LMCAP }+\beta_{4} \text { LCGE }+\mu
$$

Where: LGDP $=$ Log of Gross Domestic Product. FPIGDP $=$ Foreign Portfolio Investment as a percentage of Gross Domestic Product. LDS $=$ Log of Domestic Savings. LGCE $=$ Log of Government Capital Expenditure. LMCAP $=$ Log of Market Capitalization. $\beta_{0}=$ Constant Term. $\beta_{1}-B_{4}=$ Coefficient. $\mu=$ Stochastic Error Term.

Theoretically, it is expected that foreign portfolio investment, domestic savings government capital expenditure and market capitalization would enhance economic growth.

\section{Method of Data Analysis}

Based on the nature of the data which were time series in nature, the analytical techniques for this study are Augmented Dickey-Fuller test, Bound Co-integration Test and Autoregressive Distributed Lag. Augmented Dickey Fuller test was employed to test the stationary properties of the time series data and obtain the order of integration of the variables. This is necessary in order to avoid the problem of spurious regression. The crucial condition for the adoption Autoregressive Distributed Lag Bound Co-integration approach is that variables must be stationarity at either first difference 1(1) or the combination of first difference 1(1) and level 1(0). The Autoregressive Distributed Lag Bound Co-integration approach which was proposed by Pesaran and Shin (1999) and Pesaran, Shin and Smith (2001) is suitable for small sample data and helps to correct for endogeneity in data.

After the determination of the order of integration of the data series, Bound Co-integration was performed to establish the long run equilibrium among the macroeconomic variables employed namely gross domestic 
product, foreign portfolio investment, domestic savings and market capitalization government expenditure based on the model:

$D\left(L G D P_{t}\right)=\alpha_{01}+\beta_{1} L G D P_{t-1}+\beta_{2} F_{P I G D P_{t-1}}+\beta_{3} L D S_{t-1}+\beta_{4} L G C E_{t-1}+\beta_{5} L M C A P_{t-1}+\sum_{i=1}^{q} \alpha 1 L G D P_{t-1}+$ $\sum_{i=1}^{q} \alpha 2 F P I G D P_{t-1}+\sum_{i=1}^{q} \alpha 3 L D S_{t-1}+\sum_{i=1}^{q} \alpha 4 L G C E_{t-1}+\sum_{i=1}^{q} \alpha 5 L M C A P+\varepsilon_{l}$

Where, LGDP, FPIGDP, LDS, LGCE, and LMCAP are variables for the study. D is first difference and $\varepsilon$ is error term. The null hypothesis of no co-integration was tested against alternate hypothesis of presence of cointegration among the variables. However, following the estimation of the Bound Co-integration test, the short and long run coefficients were estimated to capture the dynamic relationships among the variables. The short run coefficients which capture the speed of adjustment and convergence to equilibrium is of the form:

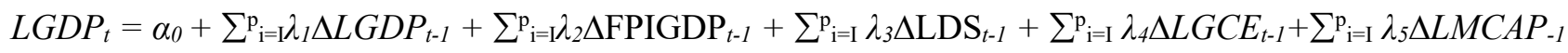

$+\Theta \mathrm{ECM}_{\mathrm{t}-1}+\mu_{\mathrm{t}}$

Where, $\lambda$ represents the coefficients of short run dynamics, $\Delta$ represents the differencing of the variables, $E C M_{t-1}$ is the error correction term resulting from the estimated long run equilibrium relationship, and $\Theta$ is the coefficient denoting the speed of adjustment to long run equilibrium when there is a shock in the system. The $E C T_{t-1}$ is expected to be negative and significance.

The long run coefficient form takes the equation: $L G P D_{t}=\alpha_{01}+\sum_{\mathrm{i}=1}^{\mathrm{p}_{1}} \Theta_{l} F P I G D P_{t-1}+\sum_{\mathrm{i}=1}^{\mathrm{p}_{1}} \Theta_{2} L D S_{t-1}+$ $\sum_{\mathrm{i}=\mathrm{I}} \Theta_{3} L G C E_{t-1}+\sum_{\mathrm{i}=\mathrm{I}}^{\mathrm{p}_{\mathrm{i}}} \Theta_{4} L M C A P_{t-1}+\mathrm{e}_{\mathrm{t}}$

\section{Results and Discussion}

Unit Root Test. The unit root properties of the data series were established with Augmented Dickey-Fuller (ADF) unit root test. The results of the ADF statistics summary conducted on the assumption of trend and intercept is presented in table 1:

Table 1. Summary of the Unit Root Test

\begin{tabular}{|l|c|c|c|c|c|}
\hline \multicolumn{1}{|c|}{ Series } & $\begin{array}{c}\text { ADF Test @ } \\
\text { Level }\end{array}$ & Probability Value & $\begin{array}{c}\text { ADF Test @ First } \\
\text { Difference }\end{array}$ & Probability Value & Remarks \\
\hline LGDP & 0.246753 & 0.9974 & -4.151018 & -3.562882 & $1(1)$ \\
\hline FPIGDP & -4.662574 & 0.0042 & - & - & $1(0)$ \\
\hline LDS & -0.591754 & 0.9727 & -4.177525 & 0.0128 & $1(1)$ \\
\hline LGCE & -1.578763 & 0.7790 & -6.773235 & 0.0000 & $1(1)$ \\
\hline LMCAP & -0.676635 & 0.9664 & -5.178405 & 0.0011 & $1(1)$ \\
\hline
\end{tabular}

Source: Authors' Computation, 2020.

The result in table 1 shows that out of all the variables employed only foreign portfolio investment as a percentage of gross domestic product is stationary at level while log of gross domestic product, log of domestic savings, log of government capital expenditure and log of market capitalization are characterized with unit root problem at level as revealed by the probabilies of the individual variables which are insignificant at $5 \%$. However, at first difference, log of gross domestic product, log of domestic savings, log of government capital expenditure and $\log$ of market capitalization are stationary at first difference as reported in Table 1. It is evidence that the data employed in the study are a mixture of level and first difference which is a necessary condition for the adoption of Autoregressive Distributed Lag Technique. Thus, this study employed Autoregressive Distributed Lag Technique.

Lag Selection Result. In order to ensure that adequate lags are selected for the Autoregressive Distributed Lag it is essential to determine the optimum lag. The optimum lag result is reported in Table 2.

Table 2. Lag Selection Criteria

\begin{tabular}{|l|l|l|l|l|}
\hline Lag & LR & FPE & AIC & HQ \\
\hline 0 & NA & 1711.729 & 21.63452 & 21.70923 \\
\hline 1 & 234.0228 & 0.542362 & 13.55024 & 13.99849 \\
\hline 2 & 20.44518 & 1.139349 & 14.14084 & 14.96264 \\
\hline 3 & $0.361799^{*}$ & $12.55813^{*}$ & $13.75348^{*}$ \\
\hline$*$ indicates lag order selected by the criterion & & \\
\hline
\end{tabular}

Source: Authors' Computation, 2020. 
The result of the lag selection based on the Akaiki Information Criterion indicates that the optimum lag for estimating ARDL regression is lag three which was adopted in this study.

Autoregressive Regressive Distributed Regression. Reported in Table 3 is the result of the autoregressive distributed lag result. It comprises of the short run coefficients, long run coefficients and the Bound cointegration test

Table 3. Autoregressive Regressive Distributed Result

\begin{tabular}{|c|c|c|c|c|}
\hline \multicolumn{5}{|c|}{ Dependent Variable: LUENMR } \\
\hline \begin{tabular}{|c|} 
Variable \\
\end{tabular} & Coefficient & Std. Error & t-Statistic & Prob. \\
\hline $\begin{array}{l}\text { Panel A: Short Run Coefficients } \\
\text { D(FPIGDP) }\end{array}$ & 0.000078 & 0.000007 & 11.753978 & 0.0000 \\
\hline $\mathrm{D}($ FPIGDP(-1)) & -0.000044 & 0.000007 & -6.629715 & 0.0000 \\
\hline $\mathrm{D}($ FPIGDP(-2)) & -0.000053 & 0.000008 & -7.061749 & 0.0000 \\
\hline $\mathrm{D}(\mathrm{LDS})$ & -0.185283 & 0.052809 & -3.508526 & 0.0027 \\
\hline $\mathrm{D}(\mathrm{LGCE})$ & 0.004343 & 0.023061 & 0.188345 & 0.8528 \\
\hline $\mathrm{D}(\mathrm{LGCE}(-1))$ & 0.134818 & 0.020578 & 6.551672 & 0.0000 \\
\hline $\mathrm{D}(\mathrm{LGCE}(-2))$ & -0.142088 & 0.018462 & -7.696086 & 0.0000 \\
\hline $\mathrm{D}$ (LMCAP) & 0.134704 & 0.033035 & 4.077633 & 0.0008 \\
\hline & -0.181024 & 0.076383 & -2.369951 & 0.0299 \\
\hline CointEq(-1) & Panel A: Lol & n Coefficients & & \\
\hline FPIGDP & 0.001234 & 0.000613 & 2.014519 & 0.0601 \\
\hline LDS & -0.254753 & 0.299696 & -0.850038 & 0.4071 \\
\hline LGCE & 0.437561 & 0.156680 & 2.792712 & 0.0125 \\
\hline LMCAP & 0.744125 & 0.204094 & 3.645996 & 0.0020 \\
\hline $\mathrm{C}$ & 4.483742 & 0.496288 & 9.034563 & 0.0000 \\
\hline R-squared & 0.789867 & & & \\
\hline Adjusted R-squared & 0.641537 & & & \\
\hline F-statistic & 5.325081 & & & \\
\hline Prob(F-statistic) & 0.000998 & & & \\
\hline & 1.733998 & & & \\
\hline Durbin-Watson stat & \multicolumn{4}{|c|}{ Panel C: Co-integration Test } \\
\hline Significance & \multicolumn{4}{|c|}{$\begin{array}{r}\text { I1 Bound } \\
\end{array}$} \\
\hline $5 \%$ & \multicolumn{3}{|c|}{2.86} & \\
\hline
\end{tabular}

Source: Authors' Report, 2020.

The result presented in Table 3 which indicates the short run result under "Panel A", shows that, foreign portfolio investment has positive and significant effect on log of gross domestic product at current period but negative effect both at first and second period lag. The short run result further shows that log of domestic savings has negative and significant effect on log of gross domestic product.

Log of government capital expenditure is found to have positive effect on log of gross domestic product at current period and lag one but becomes negative at lag two. Log of government capital expenditure is insignificance at current period but significant at first and second period lag. However, in the short run, market capitalization is established to have positive and significant effect on log of gross domestic product. Finally, the co-integration equation (CointEq(-1)) has the expected negative sign of -0.181024 and significant at $5 \%$ which confirm speed of adjustment and equilibrium relationship among the variables under study as reported in "Panel A". This implies that the model will converge to equilibrium speed of $18 \%$ in case of any error which will be corrected along the equilibrium path in the long run. The implication of the short run result is that, the effect of foreign portfolio investment on economic growth is mix.

In the long run result as reported in table 3 under "Panel B", foreign portfolio investment which is captured as FPIGDP has positive, little and significant on log of gross domestic product which implies $1 \%$ inflow of foreign portfolio investment will lead to $0.12 \%$ increase in gross domestic product. However, the effect of domestic savings is negative and insignificant with a coefficient of -0.254753 which justify the need for foreign capital in Nigeria. Finally, the long run indicates that both log of government capital expenditure and $\log$ of market capitalization have positive and significant effect on $\log$ of gross domestic product with coefficient of 0.437561 and 0.744125 respectively. 
The co-integration relationship between the independent variables and dependent variable was established using Bound co-integration technique reported in "Panel C" in table 3. The result shows that the computed Fstatistic is given as 10.44065 which is greater than the lower bound critical value of 2.86 at $5 \%$ significance level which implies that foreign portfolio investment, total savings, government capital expenditure and market capitalization have long run relationship with gross domestic product in Nigeria.

\section{Conclusion}

The study established that foreign portfolio investment enhanced economic growth more in the long run than in the short run though with little impact. These findings were supported by the dual analysis theory which stressed the role of foreign capital in supporting inadequate financial resources in capital in supporting shortage financial resources in developing countries like Nigeria (Chenery \& Bruno, 1962; Chenery \& Strout, 1966; Adelman \& Chenery, 1966). developing countries like Nigeria (Chenery \& Bruno, 1962; Chenery \& Strout, 1966; Adelman \& Chenery, 1966).

It was recommended that, recent policies of government on foreign portfolio investment should be improved and sustained. Adequate policies that would encourage investment in domestic financial instruments by foreign investors should be formulated. Policy should be formulated to make repatriation of profit or return on investment easy. There is need for government to spend more on infrastructural facilities to promote industrial sector growth. This would enable investors to invest their money in Nigeria real sector. Government should ensure that capital market is rightly positioned to take advantage of foreign financial resources by developing suitable instruments and introducing facilities that would promote quick transactions in the market. Finally, there is need for government to ensure macroeconomic stability in order to attract foreign investors.

Author Contributions: conceptualization; Adekunle Oludayo Elijah; methodology: Adekunle Oludayo Elijah; validation: Otapo Waliu Toyin; formal analysis, Otapo Waliu Toyin; investigation: Adekunle Oludayo Elijah; resources, Otapo Waliu Toyin; data curation, Adekunle Oludayo Elijah; writing - original draft preparation, Adekunle Oludayo Elijah; writing - review and editing, Otapo Waliu Toyin; visualization, Otapo Waliu Toyin; supervision, Otapo Waliu Toyin; project administration, Adekunle Oludayo Elijah; funding acquisition: Otapo Waliu Toyin.

\section{References}

1. Adelman, I.F. \& Chenery, H. B. (1966). Foreign aid and economic development: The case of Greece. The Review of Economics and Statistics, 48(1), 1-19. Retrieved from: https://www.jstor.org/ stable $/ 1924853$ ? seq $=1$

2. Aisien, L.N. (2018). The impact of exchange rate on foreign private investment in Nigeria. Asian Finance \& Banking Review, 2(2), 19-32. DOI: https://doi.org/10.46281/asfbr.v2i2.208

3. Akinbobola, T.O, Ibrahim, T.R. \& Ibrahim, O. (2017). Foreign portfolio investment-economic growth nexus in Nigeria: Co integration and granger causality analyses. Research Journal of Finance and Accounting, 8(5), 11-17. Retrieved from: https://www.iiste.org/Journals/ index.php/RJFA/ article/view/36289

4. Akinmulegun, S.O. (2018). Capital market development and foreign portfolio investment inflow in Nigeria (1985-2016). Advances in Economics and Business, 6(5), 299-307.DOI: 10.13189/aeb.2018.060503

5. Akinwale, S.O. \& Adekunle, O.E. (2019). Globalization and capital market development in Nigeria. Journal of Economics and Business, 2(2), 396-404. 10.31014/aior.1992.02.02.95.

6. Bada, O.T. (2016). Empirical evaluation of the effect of foreign portfolio investment on Nigerian economic Growth. International Journal of Comparative Studies in International Relations and Development, 4(1), 162-274. Retrieved from: http://internationalpolicybrief.org/journals/international-scientic-researchconsortium-journals/intl-journal-of-comparative-studies-vol4-no1-november-2016

7. Baghebo, M. \& Apere, T.O. (2014). Foreign portfolio investment and economic growth in Nigeria. International Journal of Business and Social Science, 5(11), 108-115. Doi. Retrieved from: http://ijbssnet.com/journal/index/2928

8. Chenery, H.B. \& Bruno, M. (1962). Development alternatives in an open economy: The Case of Israel. The Economic Journal, 72(285) 79-103. https://doi.org/10.2307/2228618.

9. Chenery, H. B. \& Strout, A. (1966). Foreign assistance and economic development. The American Economic Review, 55 679-733. 
10. Ekeocha, P. C., Ekeocha, C. S., Malaolu, V. \& Oduh, M. O. (2012). Modeling the long run determinants of foreign portfolio investment in Nigeria. Journal of Economics and Sustainable Development, 3(8), 194205. Retrieved from: https://www.iiste.org/Journals/index.php/JEDS/article/view/2320/2321

11. Ezeanyeji, C.I. \& Maureen, I. (2019). Foreign portfolio investment on economic growth of Nigeria: An impact analysis. International Journal of Academic Management Science Research, 3(3), 24-36. Retrieved from: http://ijeais.org/wp-content/uploads/2019/03/IJAMSR190304.pdf

12. Fosu, O.E. \& Magnus, F.J. (2006). Bounds testing approach to co-integration: An examination of foreign direct investment, trade and growth relationships. American Journal of Applied Sciences, 3(11), 20792085. DOI : 10.3844/ajassp.2006.2079.2085

13. Gumus,, G.K., Duru, A. \& Gungor, B. (2013). The relationship between foreign portfolio investment and macroeconomic variables. European Scientific Journal, 9(34), 209 - 226. DOI: https://doi.org/10.19044/esj.2013.v9n34p\%25p

14. Haider, M.A., Khan, M.A. \& Abdulahi, E. (2016). Determinants of foreign portfolio investment and its effects on China. International Journal of Economics and Finance, 8(12), 143 - 150. DOI:10.5539/ijef.v8n12p143

15. Ibrahim, T.R. \& Akinbobola T. O. (2017). Foreign portfolio investment and economic growth in Nigeria democratic settings. Journal of Economics and Sustainable Development, 8(5), 33-52. Retrieved from: https://www.iiste.org/Journals/index.php/RJFA/article/view/36289/37288

16. Idowu, O.O. (2015). Foreign portfolio investment in Nigeria. International Journal of Social Relevance \& Concern, 3(5), 8-19. Retrieved from: https://ijournals.in/wp-content/uploads/2017/07/3.3504wunmi.compressed.pdf

17. Makoni, P.L. \& Marozva, G. (2018). The nexus between foreign portfolio investment and financial market development: Evidence from Mauritius. Academy of Strategic Management Journal, 17(5), 1-14. Retrieved from: https://www.abacademies.org/articles/The-nexus-between-foreign-portfolio-investmentand-financial-market\%201939-6104-17-5-263.pdf

18. Mugableh, M.I. \& Oudat, M.S. (2018). Modelling the determinants of foreign portfolio investments: A bounds testing and causality analysis for Jordan. Academy of Accounting and Financial Studies Journal, 22(4), 1 - 8. Retrieved from: https://www.abacademies.org/articles/Modelling-The-Determinants-ofForeign-Portfolio-Investments-1528-2635-22-4-259.pdf

19. Ngowi, H.P. (2001). Can Africa increase its global share of foreign direct investment? West Africa Review, 2(2), 1-9. Retrieved from: https://www.africaknowledgeproject.org/index.php/war/article/view/444

20. Okonkwo, O.N. (2016). Foreign portfolio investment and industrial growth in Nigeria (1986 - 2013). International Journal of Innovative Finance and Economics Research, 4(3), 31-38. Retrieved form: https://seahipaj.org/journals-ci/sept-2016/IJIFER/full/IJIFER-S-5-2016.pdf

21. Onuoha, F.C., Okoro, P.C. \& Kingsley, O. (2018). Does foreign portfolio investment drives macroeconomic variables of West Africa? Disaggregated approach. Journal of Economics, Management and Trade, 21(7), 1-10. DOI: 10.9734/JEMT/2018/42392.

22. Pesaran, M. \& Shin, Y. (1999). An autoregressive distributed lag modelling approach to co-integration analysis. In Strom, S. (Eds). Paper Presented at Econometrics and Economics Theory in the 20th Century: The Ragnar Frisch Centennial Symposium, Cambridge University Press, Cambridge. doi=10.1.1.153.3246\&rep=rep1\&type $=$ pdf

23. Pesaran, M., Shin, Y. \& Smith, R. (2001). Bounds testing approaches to the analysis of level relationships. Journal of Applied Econometrics, 16(3), 289-326. https://doi.org/10.1002/jae.616

24. Solow, R.M. (1956). A contribution to the theory of economic growth. Quarterly Journal of Economics, 70(1), 65-94. https://doi.org/10.2307/1884513

25. Tsaurai, K. (2017). Is foreign portfolio equity investment inspired growth hypothesis relevant in emerging markets?. Euro Economica, 2(36), 78 - 90. Retrieved from: http://journals.univ-danubius.ro/ index.php/ euroeconomica/ article/view/4243 